\title{
Empowering Muslim Women Though Executive Coaching \& Mentoring
}

\author{
Fadila Grine $^{1}$ \\ ${ }^{1}$ Academy of Islamic Studies, \\ University Malaya, Kuala Lumpur Malaysia. \\ Email: fadilagrine@um.edu.my
}

\begin{abstract}
This paper examines the role and effect of executive coaching and mentoring on the empowerment of Muslim women and enhancing their levels of contribution. It further substantiates the manner in which executive coaching can accommodate both the nature and needs of Muslim women while further unleashing her respective talents, creativity and skills. The study further highlights the role and significance of coaching in spheres relevant to family, as well as social and career development. This study highlights the use of the strategic technique for personal and leadership development set to explore talents, leaders and implicit abilities. Moreover, it exhibits the flexibility of self-coaching and its appropriateness for Muslim women, especially concerning self-development, which in turn influences social and institutional development. This inquiry highlights a number of practical results which emphasizes the viability and efficacy of executive coaching on personal and institutional levels as far as the making of better world for Muslim women is concerned.
\end{abstract}

Keywords: Empowering, Executive Coaching, Muslim women, Mentoring, Skills

\section{A. INTRODUCTION}

Executive coaching is a relatively new practical strategy for the enhancement of those skills on personal, cognitive and practical levels. It aids in enhancing skills through progressive selfdevelopment and nurturing basic techniques and skills such as creative thinking, strategic thinking, alongside communication, planning and marketing; in addition to the enhancing of incorporeal values such as developing self-responsibility and a distinctive consciousness defined by success, outlining goals and further applying the required procedures to approach goals. This is undertaken under the supervision of a coach trained to ask deep and strategic questions in order to stimulate and provoke self-consciousness while simultaneously building willingness and self-responsibility. The coaches remains completely neutral and avoid directing trainees to what they believe is right for them. Instead, the decision is made in accordance with the demands and needs of the trainee which makes effective use of good listening.

Coaching revolves around several strategic questions that are carefully examined and selected as catalysts for creating stimulated thought and an enhanced ability to think strategically and practically. It depends on reinforcing positive thinking and stimulating the trainer to improve their level of thinking and further seek out the best alternatives and solutions based on the notion: "Take a step forward." The main idea of executive coaching is to prepare individuals to be leaders of their own making, and to further be responsible for their decisions and choices, while further being aided in following up their achievement plans on personal and institutional levels. Moreover, coaching also boosts the special abilities of the trainer and paves the way for leading development. This indicates the importance of applying such techniques in scientific and 
leadership development fields, and in the everyday life of the Muslim woman who is becoming increasingly responsible for various roles in the process of comprehensive development.

In the past, women used to make minor decisions related to their family life such as assuming responsibility for grocery shopping, home furnishings and other decisions rarely related to their persons or their family's future. The situation however, has changed significantly, where Muslim women presently find themselves to be living in a rapidly developing and dynamic world that is subject to continuous change. Furthermore, the Muslim woman is confronted with greater challenges influencing her family life through television as a well as a variety of stereotypes brought about by technology, that has caused their lives to be consequently be far more integrated and open.

Within this context, preparation and training is found to be a Prophetic practice and a universal rule. Whether the woman practices leadership at home or work, she is nonetheless expected to make effective decisions and to apply and extend her authority with care and caution. This in turn requires guided thinking and strategic planning, and thus effectively underscores the importance of executive coaching and mentoring. The Muslim woman found in Islamic society carries with her a sincere message to both family and social collective. This encompasses the responsibility of her nation's bright future and prospects as she effectively shapes her society's development from A to $Z$, while further serving as the maker of life and society. Added to this, she holds the ability to perform several activities on various levels due to her unique and intricate feminine disposition which enables her to hold a pen in one hand and write a poem, breast-feed her baby with the other, cook and make decisions from her desk. Nevertheless, such an ideal woman suffers from numerous psychological and social challenges, and unfortunately finds herself helpless at times; considering herself a victim of a society and subject to no mercy. On the other side of the coin, this creates high expectations of her. Although some of this is true in a manner of speaking, it is considered a significant error from an executive coaching standpoint. That is, it assumes that every individual is fully responsible for shaping their future and managing their way of life. As such, individuals should determine their goals and take appropriate action without deflecting blame onto others for their failure. Along a similar parallel, Allah (S.W.T) says: "Every soul, for what it has earned, will be retained." (Quran, 74: 38).

Quite often, Muslim women complain from husbands, fathers, sons or managers. The generally held notion is that they all frustrate women and do not grant or allow her the chance to enjoy her full range of rights (Sulaimān Bin al-Ash'ath Abū Dawūd al-Sijistānī, Izzat Ubayd al-Da'ās). The issue here however, seems to be a matter of claims as opposed to rights. Thus, whoever possesses skills works in a good manner and shows themselves to not be plagued by such feelings of depression and hopelessness, as is especially the case with women who are incapable of achieving goals on their own. In such a context, coaching and mentoring supports the pivotal role of the woman and further encourages her to develop and attain more achievements. Even though coaching may not present solutions for all challenges faced by women, it is most certain that their lives will grow easier as a result of it, which in turn will cause them to feel competent and hopeful.

\section{B. METHODOLOGY}

This study highlights the use of the strategic technique for personal and leadership development set to explore talents, leaders and implicit abilities. Moreover, it exhibits the flexibility of selfcoaching and its appropriateness for Muslim women, especially concerning self-development, which in turn influences social and institutional development. 


\section{RESULT AND DISCUSSION}

\section{Advantages Of Executive Coaching and Mentoring}

\section{a. Self-actualization}

The Muslim woman should realize her full potential and devote serious consideration and thought to which she can be and what she is capable of reaching. What are her personal goals as an independent individual whom Allah has created and prepared for a sublime goal? Coaching and mentoring systematically aids one in revealing their individual features, positive and negative aspects, while highlighting their strong points and displaying their weak points significantly enough, while also precisely specifying which fields one is in need of developing. Furthermore, they point one along paths demanding that one practice and excel, while developing the conditions and means to acquiring self-esteem. Moreover, this goes further in clarifying how one should maintain their mentality, soul, and health while further achieving harmony between their self and the world that Allah has created for their service and benefit. Muslim women should be at peace with their selves, achieve self-stability and consciously evaluate themselves with fairness. It within such a paradigm that the need for creativity and success in any life and the afterlife makes itself felt. The link drawn between human dignity and responsibility is made clear in the following two Qur'anic verses: "And We have certainly honored the children of Adam and carried them on the land and sea and provided for them of the good things and preferred them over much of what We have created, with [definite] preference" (al-Isrā': 70) and "Then We made you successors in the land after them so that We may observe how you will do" (Yūnus: 14).

The Qur'an, Sunnah and Islamic heritage are rich sources for thinking, observing and exploring ourselves; and while the concepts may vary, the essence is nonetheless singular. When a Muslim woman chooses to be part of executive coaching and mentoring, she should start from the point prior to her interest in developing her working skills, for the reason that these skills are complementary and are useless without sufficient self-awareness. The Qur'an states: "So have they not traveled through the earth and have hearts by which to reason and ears by which to hear? For indeed, it is not eyes that are blinded, but blinded are the hearts which are within the breasts" (al-Hajj: 46).

\section{b. Balance between life objectives and job burdens}

As a matter of course, the woman often chooses to acquire job skills prior to the gathering of life skills; building on the basis that in doing so she secures her future. In this context for instance, computer skills are perceived to be useful when searching for a job, but strategic thinking skills and future planning is limited to the highly intelligent and insightful. Most women are concerned with successful marital life skills, which may be for the reason that they suffer from complicated marital problems or perhaps merely seek good relationships. Despite this, women rarely recognize the relation between self-development, clarity of their goals, marital relationship success and the upbringing of children. Women may attend a number of courses on job communication skills, yet fail to link what they have learned in their family life and children's upbringing. The role of executive coaching further explores and bridges the gap and field of incompetence; something required by women in their lives, careers and relationships.

\section{c. Qualifications for success}

Success is neither an unusual case nor an issue of chance as considered by some people; especially women. This is for the reason that her success is rather different from that of the man, 
and is based on who she is while deriving from her personal features. In addition to their demand for work, women further require a stable life. Moreover, their need for self-management skills is no less important than the imperative necessity of their family management skills. Time management, on the other hand, is essential in lessening the amount of tension resulting from family and outside home responsibilities. The woman needs, as well, for her heart to be at ease (Al-Shams: 9-10), far more than the man does. This in turn indicates that she will be able to boost her positive attitudes efficiently; as found in the case of the woman whose husband threatens to depress her, whereupon she replies, "My heart is in the Hands of Allah, and you have no power over it!" This incident is an exemplar of self-management skills and positive attitude mentoring. A woman without her husband for a short while lives under self-pressure, and is transformed into a capable human power if she is offered proper stimulation and self-coaching, following which she may deduce the extent of such a potential; instead of coming by it as a present and realization on the day of her fiftieth wedding anniversary. Women should acquire the skills that establish them as self-esteem makers, organize their priorities, and become brave enough to face challenges in a responsible manner and with calmness. Instead of throwing their dreams out into the air in apathy and minimal care, women may plant it in the earth and water it with fertility, positiveness and continuous care. The universal rules will then ensure the flourishing and growing of a fruitful garden. Executive coaching and mentoring aid the woman in learning how to live, plant and harvest as opposed to buying into what does not suit her lifestyle or solutions.

\section{Skills For Working Muslim Women}

Success at work, according to universal rules of international quality, does not deal with the case of the woman as a private issue. Therefore, working women should handle their life smartly to come to an accommodation with their working life and achieve comfort, happiness and success. The first step begins when the Muslim woman forms a clear idea of herself and life with the help of the executive coaching program. Women should outline, and further define the exact meaning of success in the case of a woman; as what may be considered success in one case may be judged as failure in another. The program would decrease negative attitudes by changing the respective manner of thinking. In other words, people should come to an agreement with their selves, values and principles, instead of falling into continuous self-confrontation. Moreover, they should leave behind the past and merely chalk it up to a past effort and lesson; thereby not hindering them in any way from progressing and developing. If this is the case however, then this is considered an illness, which requires psychological treatment, as opposed to coaching and mentoring. Along such a parallel, the coach should speak frankly with the trainee from the onset of their interaction. Thus, if the case of the trainee requires a psychotherapist, then it is ineffective and difficult to solve the problem by means of coaching and mentoring, which deals with those of good health but suffers from certain difficulties, or those who are highly ambitious but suffer from failing to reach their goals.

Within work, coaching and mentoring is associated with improving the level of performance, bearing responsibilities (Muhammad Nāser al-Dīn al-Albānī in Ismā'īl bin Muhammad al-Ajlūnī, 1421 A.H), planning and carrying out duties, following up on steps for better results, selfactualization and creativity. Hence, this takes on the shape of real and manifested preparation for the future as illustrated by Ibn 'Umar (R.A.A.): "When morning comes upon you, do not expect to see the night, and when night comes upon you, do not expect to see the morning. Take advantage of your health before your illness and your life before your death (Bukhārī, Muhib al-Dīn al-Khatīb, 1400 A.H)." The main contention is therefore related to controlling the basic rules and applying them to achieve goals quickly and skillfully. One is often required to revise their self: why are they not well?, why have they not been promoted yet? Moreover, why are their papers not being 
published quickly? According to the coaching and mentoring program, the answer to these questions rests mainly in recognizing objectives, observing reasons, evaluating the situation and following up with procedures.

By following such a string of steps, the trainee will avoid languishing and settling in the mood of the problem, and instead shift to a state of approaching appropriate solutions by thinking in a manner free from pressure, and devoid of blockages of the heart and mind. Women often save energy in solving their problems by thinking, but instead end up dragging them from their home to their work, and vice versa. This is for the reason that women generally do not think to search for solutions, but remain under the pressure of the problem; assuming themselves as victims, resulting in a sort of self-fulfilling prophecy which as in turn deprives them from executing strategic thinking. On the other hand, coaching and mentoring helps women to recognize and differentiate the real problems from the insignificant and fabricated, and thus make correct decisions and come up with adequate solutions.

\section{Working Culture}

Executive coaching and mentoring affords Muslim women and female figures the chance to ascend and grow in a positive attitude far removed from confrontation with men, or accusations pertaining to the decline of womens' status. This places an end to claims for rights, and instead activates the gaining of those rights. There is no need to establish this, as Muslim women have risen and taken places in work, da'wah (Islamic propagation) and in all fields and walks of life and leadership. It is nevertheless realized through the reviewing of many individual cases that:

a. Self-responsibility plays an essential role in the success of many distinguished women in various fields of civilization.

b. Individuality has a big role in the success of many female figures. As an example, women who are successful in education, politics or business are skillful in their duties and simultaneously aware of their privacy and abilities. Such women have found their way to success as they have set their hands on unique keys that were not available or affordable to others, and therefore these cases may not be used as a general rule. For this reason, every woman ought to be exposed to coaching and mentoring programs individually. She should also be qualified for various roles according to her abilities, her social status and her health condition.

\section{Managing People Affectng The Life Of Muslim Woman}

The woman is a social and interactive creature but at the same time, suffers much from others at work. Statistics show that women are sensitive to any move or word made in their presence; calling to attention all the benefits and fallbacks associated with such sensitivity. Attributing this to the feminine nature and other hormonal reasons was neglected based on studies and statistics that reflect otherwise. The essence of this is found in that such feelings of women are caused by several reasons, most importantly: 1. Feeling downgraded and insecure; 2. Lacking training and the experience to deal with others; 3 . Treating women as men and not differentiating between their work and personal relations; and 4. A Lack of self-confidence and emotional intelligence.

Nevertheless, these reasons are remediable through coaching and mentoring on both the individual and institutional levels in order to achieve greater personal success and, as a result, institutional success. This is for the cardinal reason that women occupy many sensitive jobs in a number of spheres including teaching, management, teamwork and economics. Hence, training for 
effective teamwork and realizing behavioral manners, in addition to the nature of work relations and work tensions inside and outside the institution grant the woman the opportunity and capability to serve the dynamic role and position of an effective and powerful participant throughout a wide array of different institutions. In this regard, her voice is heard and she shares respect with other employers at her work. Moreover, she has confidence in others and leaves out arrogance and the downgrading of others. She utilizes her energy and power for more achievements so that she may introduce her services and secure her reputation as a trainee, employer or even a businesswoman. In this, she would follow the example of Khadijah (R.A.) who undertook an executive business career. Khadijah (R.A.) was a paragon when it came to manners and business credibility, to the extent that no one would object to naming her 'the Lady of Business' and 'the Mistress of Ladies in Paradise.' This effectively opens the door for women to compete and build achievements. What therefore remains, is Muslim women excelling in coaching and mentoring in order to participate in leading the world towards development on an Islamic basis. This is possible through acquiring a strong belief background, clear religious rights and Islamic knowledge which lead her to success.

\section{Criteria Of Gain And Loss: An Islamic Insight}

The criteria for gain and loss varies according to the Islamic perspective (Muhammad Nāsir al-Dīn al-Albānī , 1408 A.H), based on a number of forms of thinking and approach. Some of them are close to the Islamic view whereas others are very distant. Such information should be realized among the Muslim woman's priorities, in addition to specifying objectives and defining success. Allah (S.W.) states in the Qur'an: "But among them is he who says, "Our Lord, give us in this world [that which is] good and in the Hereafter [that which is] good and protect us from the punishment of the Fire" (Quran, Chapter I: 201). Success is more like a garment that fits a person if it is their size, and suits their taste and personality. Thus, if the Muslim woman wears the outlook of a woman who experiences spiritual deprivation and a materialistic trend and suffers to earn money to make a living without the help of even her father, then the objectives she looks forward to are not adequate for her. Such an example is experienced by many Muslim women all over the world, simply for the reason that she is European and typified as blonde. It goes without saying that women should succeed, be strong and well qualified on the spiritual and materialistic levels. However, the social priorities and responsibilities, as well as the spiritual values women hold to impose upon them a different order for priorities that vary from one woman to another, and from one society to the next.

Coaching and mentoring helps one take a step further towards the future. The importance is not pinned on whether the woman fails or succeeds. Rather, the most important matter is how she can approach her objectives, and furthermore, if there is a better and safer means for her to achieve her aims. Coaching grants every woman a chance to understand how success is achieved so that she may be an expert. The coaching program is suitable for every woman; whether she is a housewife or a leader. It encourages her to think to her own benefit, listen to others, and speak out loudly and find suitable solutions. This, indeed, will help her to become more self-confident and improve her skills continuously, exactly as is the case with a toddler who walks the first step and falls in others until he or she learns to walk independently. This is known as strategic development for individuals and institutions, which is introduced by executive coaching as an alternative to old teaching techniques. 


\section{Skills To Empower Muslim Woman In All Fields}

\section{a. Spiritual Skills}

Allah (S.W.) says: "And [by] the soul and He who proportioned it and inspired it [with discernment of] its wickedness and its righteousness" (al-Shams: 7-8). Neither psychology nor spiritual coaching books, which are widespread in Western bookstores, provide a clear process for selfpurification and progress as the Holy Qur'an and the Sunnah did. That is, the Qur'an is a continuous daily reminder, which washes away the accumulated dust (sins) of the day and night with pardon and forgiveness. On the other hand, the Sunnah is a comprehensive method of life that maintains the stability of physical organs and senses, while also acting as a continuous means of purification for the heart and soul. Coaching, in Muslim societies is considered to be a new means for da'wah, especially in calling women to be religious after having understood the essence of Islam and its rituals. It also takes on the role of protecting them from following base desires, and strengthens their spiritual condition; effectively shifting it into stored energy and a beginning for achievements. Hence, if Muslims utilize this means of da'wah, then da'wah would shift to the level of self-treatment for each case in flexibility and privacy. This is exemplified by the case of fatwā (Islamic ruling) where two persons may receive completely different fatwā for the same question.

Moreover, the Prophet Muhammad (PBUH) used to care for each of His companions, providing them with spiritual care and guidance. Spiritual coaching acts as purification even though the terms may be different. The Prophet (PBUH) addressed His companions one day and asked, "Who among you is fasting today?" Abu Bakr replied: "I am." He said: "Who among you has attended a funeral today?" Abu Bakr replied: "I have." He said: "Who among you has fed a needy person today?" Abu Bakr said: "I have." He then said: "Who among you has visited a sick person today?" Abu Bakr said: "I have." The Prophet then said: "These (traits) are not combined in a person but that he will enter paradise". The new concept presented here is that each person is encouraged to bear responsibility in exploring their own spiritual aspects and probe the degree of deprivation they suffer from. This enables them to determine the amount of purification needed in order to progress and purify the spirit following the manner set by the Prophet Muhammad (PBUH) who practiced this and guided people to practical steps of self-development that will hold true to the Day of Judgment. Thus, if the woman excels in spiritual self-coaching, she will enjoy a great deal of spiritual and religious joy that will effectively bolster her and pave the way for her achievements and distinction. Some examples which may be followed during coaching are as follows:

What is your aim in performing prayers?

To become nearer to Allah (S.W.T).

Do you feel yourself to be closer to Allah (S.W.T) when you pray?

Not very much.

What do you mean by 'not very much'?

I am not content with my prayer.

What can you do to feel content with your prayer?

I can work on focusing more during my prayers.

What are the procedures that help you to keep your focus?

I can concentrate on the Qur'anic verses I am reciting.

How can you keep concentrating?

By repeating the verses I was not attentive in and by repeating the whole prayer if I did not concentrate in my prayer. 
Can you use this solution continuously?

Yes.

Make a daily scheme for prayers and tick the box in front of each prayer you have concentrated in, and evaluate your self after a month.

While this is a rather simple example of coaching, it is enough to point out the following:

1) The woman performing prayer is the one who observes and discovers, and not the coach.

2) The woman who prays is the one who suggests the solution and the working plan.

3) The coach helps in directing the trainee for continuous training and grants the trainee a chance to observe and remark throughout the daily scheme.

4) The result: the women performing prayer has noticed a daily improvement in her focus during prayers.

5) This practical improvement in prayer has helped the woman to proceed and feel self-content.

\section{b. Cognitive Skills}

Women need to possess a subtle knowledge about themselves, the environment, their field of interest and their role. Thus, any neglect or shortage occurring in one of these fields will result in a regression of the woman's performance on all levels. This is known as the disastrous disordered performance, which usually results due to a lack of knowledge (Muhammad Nāsir al-Dīn al-Albānī, 1400 A.H). It is for this reason that a woman may destroy her life while she intends to live in love, ruin her children with blind love, lose her husband as she is ignorant of the art of marital relations and hurt herself because she does not make use of chances for development. Coaching is a dynamic strategy that urges women to ask questions, to acquire knowledge and to gain skills. The education of the woman should therefore take into consideration her discretion when she chooses to be a successful mother and not a successful employer while enjoying her role as a homemaker. In this case, coaching also provides her with the essential skills to manage her own institution (i.e., her family). Coaching will also provide help and assistance for the female writer by teaching her the skills of modern writing, which also emerges with respect to her discretion; uninfluenced by the coach. Teaching a female the skills of speech, conversation and time management to become a prominent caller for Allah also takes her wishes into primary consideration. Regardless of her field of interest, the woman should master the main concepts of her field; whether she is a mother, wife, director, educator, prime minister or businessperson. Although some skills are essential for all women, coaching and mentoring allow the woman to explore herself and determine her needs, which may vary from one woman to another. Indeed, this is the main feature of coaching, something rather essential for the development of the Muslim woman; especially if renowned female figures are involved in the process of the Muslim women's comprehensive development.

In most situations, women choose to hand over the process of thinking to others, in a sense going in line with the proverb, which dictates: "Do not think, as the king will think for you." However, even if this 'king' was a loving husband, a warmhearted father or a kind brother, the nature of the woman and her personality is not fully established and cannot flourish without objective thinking and the ability to analyze situations and make use of them. Critiqued personal thinking will lead her to progress constantly, and strategic thinking will grant her a step forward. The Muslim woman should pay attention to creative thinking and cognitive skills more than other women should. By reading and reflecting on the holy Qur'an every day; the Muslim woman can begin to explore talents, and recurrently train the mind with the empowering skills of self-deterministic cause and effect. 
Muslim women should think of the solutions and in turn find adequate answers. Indeed, making mistakes while finding out answers is the shortest way to the solution. Executive coaching and mentoring (for Muslim female scholars, students, mothers and employers) is sufficient to explore the abilities of female jurists, scholars, researchers and creative women in all fields. That is, executive coaching helps in exploring the abilities of the mind and takes the woman step by step towards a bright future which Allah (S.W.T) granted to humanity upon granting them with perception, cognition, and the ability to explore the rules of development in both the human being and the world at large.

\section{Personal Skills And Responsibility}

While many women who have obtained high academic degrees and have been gifted with high levels of intelligence may have been awarded numerous medals in their academic and technical fields; they nonetheless suffer from working within small groups and lacking skills of leadership. This in turn deprives people from benefiting of their vast knowledge and experiences. Some may even choose to avoid meeting people if she can help it, and instead compose books for half a century. This is considered to be a social disability and a deficiency in the realm of personal skills and responsibility. For a person to perform in his/her full capacity, they must establish successful social relationships on the personal and professional levels. This may be achieved through planning, self-educating oneself by being aware of personal insufficiency, and then following through by bridging the gap between their self and people in a bid to benefit society and gain contentment and happiness; which not only generates intrinsic satisfaction, but pushes the individual forward onto achievement and success.

As an example, I trained a female teacher who was active and hardworking but suffered from problems with her co-teachers in the workplace. During the process of self-coaching, I found through the questions I asked her that she lacked the appropriate skills to deal and interact with her friends at work. I also found that she had furthermore carried out a number of mistakes with her co-teachers. Throughout the coaching program, she managed to develop a plan, which she named 'the natural healthy relation.' Her friends began to realize that she had changed; with the result that she became clearer to them and more social, which encouraged her to pursue her work although she had planned -prior to the coaching program- to leave the school and work in a faraway place based on the assumption that everyone hated her. Our female teacher became effectively more self-confident and empowered. She experienced the solving of her previous problems, and furthered her work through harmony, transparency and social interaction. Under the coach's remark section, I later wrote: 'She has learned to take responsibility for her mistakes on her own: a successful coaching case.'

\section{Communication Skills}

It is striking and surprising that a woman living in such an age of globalization and increasingly rapid technology and information can lacks experience and expertise when it comes to using such technology in developing her family, work, and her children's upbringing. In a the newly industrialized and rapidly developing country Malaysia, it is astonishing to find a female university lecturer who is unable to carry out the simple task of attaching a file to an e-mail; instead using old teaching methods and techniques to instruct tech savvy students, who treat technology and gadgets as an extension of their body. This deficiency and technophobia in the Muslim women's world specifically, is a drawback that may be solved by means of executive coaching and mentoring. Moreover, it may also be tackled by learning the latest communication skills both inside and outside home; alongside their respective use and practice according to the role of the woman; 
whether she be a school teacher, businesswoman, Islamic propagation caller or a leader. Ultimately, women should excel in skills of interactive communication and make use of technology. This not only provides a definite boost in terms of sealing the gender inequality gap, but also further serves as a catalyst for self-confidence and development; thereby opening doors to a potential for acquiring more skills while breaking the ice that kept from upgrading her persona.

\section{Physical Skills}

Unfortunately, many Muslim women lack bodily fitness and physical skills, which require muscle control, in addition to the bodily ability necessary for performing highly strenuous tasks. In order for a person to come to terms with whether they have already obtained those skills or not, they ascertain their familiarity with features of physical skills as pointed out by human development scholars. A person should be capable of dealing with all situations accordingly and quickly. This means that successful Muslim women should be able to walk, jog and write well at an average rate of speed to reflect competence. Among the features of physical skills and fitness is the invaluable ability to operate under pressure. It is for this reason that soldiers in military coaching are exposed to pressure such as the lack of sleep, fatigue and difficult tasks requiring one to draw on reserves of will, perseverance and strength beyond the ordinary. This in turn helps them to gain flexibility and tolerance. Recent problems faced by Muslim women have shown a very weak tolerance and threshold for pressure in personal and working levels. A simple comparison between the lives of the generation of mothers and those of their grandmothers would not only show a severe disparity between the two, but the latter's ability to adapt to more difficult situations as they lived harder lives and in doing so acquired better tolerance.

The coaching program is also inclusive of observation of the trainee and their respective tolerance, in addition to placing them under pressure in order to crystallize their opinion, will and their skill to the extent desired by the trainee. While Muslim women may find it somewhat nonsensical or preposterous when asked to exercise, the reality remains that exercising is not only beneficial in terms of beauty purposes but also for strength, energy and control. It is not a standoff or confrontation with men, but rather that a beautiful strong woman is more likely to react in a healthy manner and suffer from less self and work induced pressure. On the other hand, a weak and easily exhausted woman usually lives a miserable life, and experiences progressive hardships with those around her. On a more significant note however, coaching provides a sense of time value and boosts responsibility and accountability towards time as the period needed for achievements specifies the state of success or failure. In this light, numerous skills nowadays draw on or are directly related to strategic thinking; as with the skillful footballer who thinks strategically to make a goal or two, whereas the fatigued footballer only wishes to end the game safely and peacefully.

Fatigue and boredom hold a high likelihood of hindering women's progress. Added to this, she may be inhibited due to her children getting sick, her husband falling ill or her trade failing due to her lack of experience. Continuous executive coaching, self-learning and the acquiring of basic skills help women to perform better, and progress on the personal, professional and social levels. Moreover, there is a direct relationship between coaching and the number of decreased mistakes and increase in good performance in all fields and occupations.

\section{Coaching For Personal Relations}

Coaching and mentoring, as previously mentioned, involve all fields and walks of life including the personal, professional and social skills. This includes the sphere of personal relations as it plays a significant role in the midst of these fields, and is further affected by development. This is why 
executive coachers pay high attention to personal relations, with some specializing in marital relations to secure positive relations towards growth and development and further eliminating negative effects on institutions and coaching standards to achieve successful and interactive personal relations. Indeed, the family has been regarded as the building of block of society since ancient times with mentions of its significance and respective impact on society found as early as 2300 years ago in Aristotelian thought. Books on coaching establish many standards varied from one coacher to another towards this end. These standards may be set as the criteria for correct relations; otherwise, personal relations may be set accordingly. The standards include:

\section{a. Deeper relations}

The coacher would ask a number of selective questions to reveal the nature of the relation and its deepness. Thus, the goal is explored through the relation. The answer to the following question: "Are you interested in this person? Answer by using numbers from 1 to 10 " would say much about the status of the relation and its importance in human life. The decision could then be made to pursue and progress or terminate this relation.

For example: a woman complains about her friend who disturbs her every day through phone calls and speaks to her of other people's news. I asked her: How valuable is this relationship in your life? She said: Somewhat. I asked: How much would you give this relation out of 10 ? She said: 2 . I said: Do you think you should improve this relationship or keep away from it? She chose to keep away from it, as the relation was shallow and meaningless.

\section{b. Guided and clear relations}

Some personal and trade relations are almost certainly headed to failure once they begin as they tend to be characterized by an absence of clarity and in incompetence. During my coaching lessons, I faced a number of women who provided me with vague answers related to their social and family relations. I asked, for instance: Why did you choose this person to be your friend if you think she is annoying? The answer usually sounds like this: "I have not thought much of this relationship before. The relationship actually lacks any objective, and l've just thought about it now." With the amount of existing marital discord as a an abstract yardstick, it is more than likely that a significant amount of marital relations are often practiced spontaneously and haphazardly; while such a sensitive relationship should be studied and nurtured more than any other relationship in order to achieve a healthy and comfortable marital relationship. Some answers provided by trainee women on the nature of their marital relationships with their husbands are stark and rather terrifying. I question them: "Do you have a clear relationship with your husband?" With their response being: "I do not understand." Upon which I explain: "Do you recognize the status of the relationship between you and your husband?" Some reply: "Love", "Marriage" or "I do not know", with the latter being the most frequent answer. Executive coaching provides women with insights regarding the nature of relationships and its variants and increases their ability to cure it, treat it or maintain it.

\section{c. Confidential relations}

It is impossible to have clear and good relationships without the existence of confidence. The Prophet Muhammad (S.A.W.) was known by his people as 'the faithful.' This feature was clearly reflected in those dealing with Him and could be easily recognized in such interactions. However, if such a feature were missing, the relationship would end the minute it began. Coaching, guiding and their form of questions effectively evaluate the basis confidence in personal relationship. Hence, a simple question such as, "Can you depend on your husband when you face a real 
problem?" would effectively reveal the degree of confidence which may or may not have been considered by the trainee before. In the case of a friend, the same question is asked, "Can you depend on this person?" One may find it hard to evaluate the nature of the relationship until such queries are posed to them.

\section{d. Positive relations}

There are innumerable tiresome relationships, which influence the person's psychological and physical health; especially in a world replete with illiterate women. For instance, relations may face negativity, which directly and detrimentally affects decisions and reflects a non-healthy lifestyle. A well-trained woman in personal relations can easily diagnose friends, and positive and negative relations. Simple questions such as, "How much of your life is influenced by your friend?" or "Do you feel comfort after meeting this friend?" mostly yield answers such as: "I feel self-conscious because she makes me listen and talk of unimportant things" or "I feel frustrated whenever I meet this woman." Coaching is not meant to judge others, but to rather train people how to deal with similar cases in the future. This allows the person to become familiar with the criteria of proper relations and thus empowered, act accordingly.

\section{e. Open, comfort and continuous relations}

Sometimes, relations tend to be vague which cause extra trouble for the person. In the Arabic world, for instance, one often feels shy to turn away friends. One does not ask daring questions such as: "What do you mean?", "Why do you want me to do this or that?" or "What exactly do you want from me?" Such social pressures effectually drives relationships into a form of harmful vagueness. Vague relationships may even be found among members of the same family; with a woman potentially finding her husband vague, or vice versa. This largely depends on the degree of clarity utilized during communication and dealing with one other. It also requires some effort for explanation, as in the case of the western mother who explains to her child why he or she is being punished. In sharp contrast to this however, many eastern mothers beat their children while the child does not even comprehend or know the behind being beaten. Clarity can be acquired through coaching and practicing to be clear with others. Many people tend to be vague as a matter of habit and dislike explaining their actions or simply speaking, but when they realize the great benefits inherent in being clear and acquire the appropriate communication skills are witness to their lives being changed. A female trainer decided to record herself while talking to her husband and found that her husband did not answer her questions. After observing the conversations, she realized that she usually asked five questions at one time.

\section{f. Pure relations}

Humans hold significant values that should be channeled into their relationships and working life. Pure relationships are truthful and rightful, and further require the practicing of the essential mores of humanistic conduct such as showing mercy to one another, being cooperative, maintaining good brotherly or sisterly relations, keeping in touch with relatives and taking care of friends and family. In other words, that one do equally to others in accordance with what one would wish for their own self. This is embodied in the narration of the Hadith of the Prophet (S.A.W.): "None of you is a true believer until he likes for his brother what he likes for himself" (Muhammad bin Ismā'il al-Bukhārī, 1400 A.H), and "The believer to the believer is as a building whose different parts support one another. The Prophet then clasped his hands with his fingers interlaced" (Ibid) which effectively indicates that the believers' support one another through cooperation and solidarity. Social relations in the Islamic society are of pure origin as they are judged by norms and divine 
rules that are not restricted to people's modes and passions. The wife, for example, who may be disliked, as well as the friend that we do not feel comfortable with and even the neighbor who shouts disturbingly all have rights upon the individual, and thus one is required to look after them with an open-heart and dedication in return for collective brotherhood and sisterhood. Executive coaching helps in spreading a culture of mercy and solidarity amongst people, specifically carried out through trainings on work relations, neighborhoods and in mosques. This is considered a revival of the Prophetic Sunnah (S.A.W.), morals and goodness in treatment Muhammad Nāsir alDīn al-Albānī, 2003) The coach may therefore ask numerous questions, with their answers being considered a self-criticism of the status of social relations and responsibilities.

\section{g. Healthy Relations}

Western studies have discussed in some depth what is considered a 'healthy relationship'. It is important to know what this concept refers to from a Western perspective, that we may evaluate our relations accordingly. Westerners apply the understanding of a 'healthy relationship' when a number of basic elements are found, including healthy habits, thinking good of others, developing one's self, continuous self-improvement, increasing self-confidence, increasing self-responsibility, developing one's habits, setting goals, approaching success and having the ability to face life's problems. These elements however, are all required from an Islamic point of view. Morals are nonetheless morals, and as such, the culture of 'healthy relationships' is a goal that may be accomplished through continuous coaching on personal and institutional levels. Women, in particular require this form of coaching as they need to properly conduct professional and personal relations while excelling in creating substantive meaningful relationships that set her personal and professional life at ease in comfort. It is useful to make use of the Western notion of the 'healthy relationship' by applying it to our relations. We may then ask in terms of coaching: Is this a healthy relationship? Does this relationship help in development and achieving success or does it hinder and bring about negativity? These questions, among others, should be introduced to continuous coaching and thinking for the sake of improvement and progress.

\section{CONCLUSION}

This research is a humble effort towards the establishment of executive coaching and mentoring. Indeed, many readings on this issue have been made to find solutions to the problems encountered in various fields of the Islamic world, among which are those related to women and education. However, references available on this subject have not been used directly in this research. Furthermore, the research does not refer to a specific reference or book in the relative area, although plenty of references on executive coaching exist in English and French languages. This is for the reason that this research is directed towards the Muslim society, which allows it to be nurtured in an Islamic context where quoting and copying from foreign references would cause it to be less effectual. This means that the subject in hand is relatively new, and is based on personal experience and practice.

This study is an attempt to establish a number of primary concepts and criteria that are applicable to becoming the basis for coaching and mentoring from an Islamic perspective, especially in dealing with the Muslim woman's development in the Islamic world, in general, and Saudi Arabia, in particular. Coaching has proven its success in enhancing the wheel of progress and continuous development in Western societies. As a Muslim woman who has lived in the west for a considerable period of time, studied coaching and mentoring and practicing it in teaching and education while continuing to practice it in Malaysia particularly at the women's level, I have found that it is a significant technique to approaching goals. 
Furthermore, I find it to be far better than, and in fact surpassing consultation and traditional learning. This is so for two reasons: namely that the coaching technique teaches trainees to depend fully on themselves and bear their own responsibility when making personal decisions. It allows them to follow up their decisions through practical procedures under the supervision of the executive coach. Coaching is different from courses given for enhancing skills due to its privacy and personal follow-up. The other reason is found in its purpose of directing the trainee towards the future without hesitation or looking backward. The coach asks deep questions of the trainee to allow them to focus on the future rather than the past, without any interference in the form of advice or suggestion. This in turn gives the trainee the chance to be free from past mistakes, and to ensure that they receive solutions from not from outsiders, but rather from their own selves. This consequently encourages trainees to adopt their own opinions, as they are the ones who have succeeded in providing solutions to problems. The coach then will only follow up on the coachee's procedures and applications until the goal is approached. This technique has proven its usefulness for Muslim woman as it helps her to discover herself and her talents, and to employ her creative abilities to bear her own responsibilities in this life and the hereafter. 


\section{References}

Dhilāl al-Jannah fi Takhrīj 'al-Sunnah' li Ibn Abī Aāsim. (Al-Maktab al-Islāmī).

Ismā'īl bin Muhammad al-Ajlūnī, Ahmad al-Qallāsh (ed.), Kashf al-Khafā' wa Muzīl al-Ilbās ammā Ishtahara min al-Ahādīth ala Alsinat al-Nās. (Mu'ssasat al-Risālah).

McMahon, Gladeana. (2010). 01 Coaching Strategies and Techniques. Hove: Routledge.

Muhammad bin Ismā'îl al-Bukhārī, Muhib al-Dīn al-Khatīb (ed.), al-Jāmi' al-Sahīh al-Musnad min Hadīth Rasuli-llah wa Sunanihi wa Ayyāmihi. Cairo: al-Maktabah al-Salafiyyah.

Peltier, Bruce. The Psychology of Executive Coaching: Theory and Application. New York: Routledge Publisher, 2nd ed.

_., Sahīh al-Adab al-Mufrad li al-Imam al-Bukharī. (Dār al-Siddīq).

Silsilat al-Ahādīth al-Sahihah wa Shay' min Fiqhihā. (Maktabat al-Ma'ārif).

Stern, Lew. (2008). Executive Coaching: Building and Managing Your Professional Practice . Hoboken, N.J.: John Wiley \& Sons.

Sulaimān Bin al-Ash'ath Abū Dawūd al-Sijistānī, Izzat Ubayd al-Da'ās (ed.), Sunan Abī Dawūd. (Dār al-Kutub al-IImiyyah).

, Zuhayr al-Shawīsh (ed.), Sahīh al-Jāmi' al-Saghīr wa Ziyādatuh. Beirut: al-Maktab alIslāmī. 